\title{
The effect of olive or linseed oils supplemented with pure saturated fatty acids on serum cholesterol levels in the rat
}

\author{
P. Hanczakowski ${ }^{1}$ and B. Szymczyk \\ National Research Institute of Animal Production, \\ Department of Animal Nutrition and Feed Sciences \\ 32-083 Balice, Poland
}

(Received 2 November 2005; revised version 1 February 2006; accepted 12 April 2006)

\begin{abstract}
A 6-week experiment on rats was performed to evaluate the growth-promoting and cholesterolaemic activity of olive and linseed oils mixed with pure myristic, palmitic or stearic acids. Each oil was mixed with each acid in a 1:1 w/w ratio. At the end of the experiment, blood was collected by cardiac puncture and total serum cholesterol (TC), HDL and LDL fractions, and serum triacylglycerols (TAG) were estimated. Mixing oils with pure fatty acids resulted in higher body weight gains. The longer the carbon chain of the acid, the higher were the body weight gains of the rats $\left(1.99,2.39\right.$ and $2.57 \mathrm{~g}$ per day for $\mathrm{C}_{14}, \mathrm{C}_{16}$ and $\mathrm{C}_{18}$, respectively). Myristic acid gave the highest level of TC $\left(84.5 \mathrm{mg} \mathrm{dl}^{-1}\right)$, while its mean content in pure fatty acids was only $77.34 \mathrm{mg} \mathrm{dl}^{-1}$. Myristic acid also accounted for the largest increase of TAG content in the case of both oils.
\end{abstract}

KEY WORDS: rat, saturated fatty acids, serum lipids

\section{INTRODUCTION}

High serum cholesterol levels are known to be one of the major risk factors for coronary heart disease (Flickinger and Huth, 2004). The triacylglycerol level is also a probable independent risk factor for this condition (Benz and Sutter, 2004). Both cholesterol and triacylglycerol levels are largely food/feed dependent and fat and its fatty acid composition seem to be one of the most important factors (Nagata et al., 2004).

Many experiments have been performed to establish how particular fatty acids affect blood cholesterol levels. Generally, it has been found that saturated

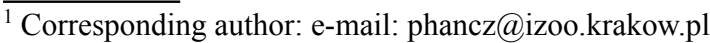


fatty acids (SFA) are hyper-, and polyunsaturated fatty acids (PUFA) are hypocholesterolaemic (Dorfman et al., 2005). The cholesterolaemic activity of monounsaturated fatty acids (MUFA) is still not precisely established (Nielsen et al., 1995; Rajaram et al., 2001).

Experiments on the effect of fatty acids on cholesterol levels are usually performed using natural fats, which are mixtures of various fatty acids and may contain other bioactive substances that can modify their effects (Trautwein et al., 1999; Perona et al., 2003). Only a few experiments have been carried out with synthetic fatty acids (Hanczakowski et al., 2004) or synthetic triacylglycerols (Nagata et al., 2004). The results of the former study suggested that pure saturated fatty acids $\left(\mathrm{C}_{12}-\mathrm{C}_{18}\right)$ were not hypercholesterolaemic when compared with olive oil, the main component of which is oleic acid $\left(\mathrm{C}_{18: 1}\right)$.

The aim of this study was to determine the cholesterolaemic activity of natural oils (olive or linseed oil) when mixed with pure saturated fatty acids.

\section{MATERIAL AND METHODS}

\section{Diets}

Eight experimental diets were prepared. In the first virgin olive oil was the only fat source. In diets II-IV, half of the olive oil was replaced by myristic, palmitic or stearic acid, respectively. Pure linseed oil was the fat source in diet V, and half of it was replaced by synthetic acids in diets VI-VIII. Each diet contained $10 \%$ fat. The composition of the diets (according to Eggum, 1973) is given in Table 1.

Table 1. Composition of experimental diets, ${\mathrm{g} \cdot \mathrm{kg}^{-1}}^{-1}$

\begin{tabular}{|c|c|c|c|c|c|c|c|c|}
\hline \multirow{2}{*}{ Ingredient } & \multicolumn{8}{|c|}{ Groups } \\
\hline & I & II & III & IV & $\mathrm{V}$ & VI & VII & VIII \\
\hline Soya protein isolate & 200 & 200 & 200 & 200 & 200 & 200 & 200 & 200 \\
\hline Olive oil & 100 & 50 & 50 & 50 & - & - & - & - \\
\hline Linseed oil & - & - & - & - & 100 & 50 & 50 & 50 \\
\hline Myristic acid $\left(\mathrm{C}_{14: 0}\right)^{2}$ & - & 50 & - & - & - & 50 & - & - \\
\hline Palmitic acid $\left(\mathrm{C}_{16: 0}\right)^{2}$ & - & - & 50 & - & - & - & 50 & - \\
\hline Stearic acid $\left(\mathrm{C}_{18 \cdot 0}\right)^{2}$ & - & - & - & 50 & - & - & - & 50 \\
\hline Saccharose & 200 & 200 & 200 & 200 & 200 & 200 & 200 & 200 \\
\hline Cellulose $^{3}$ & 40 & 40 & 40 & 40 & 40 & 40 & 40 & 40 \\
\hline Mineral mixture ${ }^{4}$ & 40 & 40 & 40 & 40 & 40 & 40 & 40 & 40 \\
\hline Vitamin mixture $^{5}$ & 20 & 20 & 20 & 20 & 20 & 20 & 20 & 20 \\
\hline Maize starch & 400 & 400 & 400 & 400 & 400 & 400 & 400 & 400 \\
\hline
\end{tabular}

${ }^{1}$ protein $(\mathrm{N} \times 6.25)$ concentration (g per $\left.100 \mathrm{~g}\right)$ : $94.15 ;{ }^{2}$ Sigma-Aldrich, $2005 ;{ }^{3}$ Whatman CF11 (SigmaAldrich); ${ }^{4}$ mineral mixture provides into $1 \mathrm{~kg}$ of diet $\mathrm{g}: \mathrm{CaCO}_{3} 12.4, \mathrm{KH}_{2} \mathrm{PO}_{4} 13.2, \mathrm{Ca}\left(\mathrm{H}_{2} \mathrm{PO}_{4}\right)_{2} 3$, $\mathrm{MgSO}_{4} \cdot 7 \mathrm{H}_{2} \mathrm{O} 4.2, \mathrm{NaCl} 6.7, \mathrm{MnSO}_{4} \cdot 4 \mathrm{H}_{2} \mathrm{O} 0.21, \mathrm{ZnSO}_{4} \cdot 7 \mathrm{H}_{2} \mathrm{O} 0.025, \mathrm{FeSO}_{4} \cdot 7 \mathrm{H}_{2} \mathrm{O} 0.13, \mathrm{KJ} 0.032$, $\mathrm{CuSO}_{4} \cdot 5 \mathrm{H}_{2} \mathrm{O} 0.098 ;{ }^{5}$ vitamin mixture provides into $1 \mathrm{~kg}$ of diet I.U.: vit. A 4375 , vit. $\mathrm{D}_{3} 1750 ; \mathrm{mg}$ : vit. $\mathrm{B}_{1} 17.5$, vit. $\mathrm{B}_{2} 35$, vit. $\mathrm{B}_{6} 35$, biotin 0.8 , PABA 10 , nicotinamide 100 , panthothenic acid 35 , vitamin $\mathrm{E}$ 8.7 ; $\mu$ cg: vit. $\mathrm{B}_{12} 33$; g: cholin chloride 1 
Rats

Eight groups of 50-day-old male albino rats, each weighing about $160 \mathrm{~g}$ at the beginning of the experiment, were kept individually in plastic cages and had free access to feed and water. Each group comprised six animals. Body weight was measured at the beginning and the end of the experiment and feed consumption was measured daily.

\section{Blood sampling}

After the 6 weeks of the experimental period were completed, the rats were fasted overnight $(12 \mathrm{~h})$ and anaesthetized with thiopental (Biochemie $\mathrm{GmbH}$, Vienna). Blood was collected by cardiac puncture and serum samples were separated by low-speed centrifugation ( $1500 \mathrm{~g}$ for $15 \mathrm{~min}$ ).

\section{Chemical analyses}

Fatty acids were analysed as methyl esters in a $25 \mathrm{~mm}$ id $\times 30 \mathrm{~m}$ long fused silica SP 2330 capillary column (Supelco Inc., Bellefonte, USA) using a HewlettPackard gas chromatograph model 5890 equipped with a flame ionization detector.

The total cholesterol (TC) content of rat blood serum was assayed enzymatically according to Allain et al. (1974) and its high-density lipoprotein fraction (HDL-C) according to Warrick et al. (1982). The low-density lipoprotein fraction (LDL-C) was calculated as the difference between TC and HDL-C. The serum triacylglycerol (TAG) content was estimated according to McGowan et al. (1983).

\section{Statistical analysis}

Statistical analysis of treatment effects was conducted by two-way analysis of variance (MANOVA) with comparison of means by Duncan's multiple range test at $\mathrm{P}<0.05$ and $\mathrm{P}<0.01$ levels of significance using the Statistica v 5.1 package.

\section{RESULTS}

The fatty acid content of the experimental diets was generally the mean of the main fatty acids of the oils used, oleic in the case of olive oil diets and linoleic in the case of linseed oil diets, and the added synthetic acid (Table 2). 
Table 2. Fatty acid composition of fat in experimental diets, $\%$ of total FA

\begin{tabular}{|c|c|c|c|c|c|c|c|c|}
\hline \multirow{2}{*}{ Fatty acid } & \multirow{2}{*}{$\begin{array}{c}\text { Olive } \\
\text { oil }\end{array}$} & \multicolumn{3}{|c|}{ Olive oil + acid } & \multirow{2}{*}{$\begin{array}{c}\text { Linseed } \\
\text { oil }\end{array}$} & \multicolumn{3}{|c|}{ Linseed oil + acid } \\
\hline & & myristic & Palmitic & stearic & & myristic & palmitic & stearic \\
\hline $\mathrm{C} 12$ & 0.1 & 0.1 & 0.1 & 0.1 & 0.1 & 0.4 & 0.1 & 0.1 \\
\hline C14 & 0.1 & 49.5 & 1.0 & 0.4 & 0.1 & 49.1 & 0.9 & 0.4 \\
\hline $\mathrm{C} 16$ & 11.6 & 5.9 & 54.4 & 5.6 & 7.0 & 3.6 & 51.9 & 3.4 \\
\hline C16:1 & 0.6 & 0.4 & 0.2 & 0.2 & 0.1 & 0.1 & 0.0 & 0.0 \\
\hline C18 & 3.8 & 1.6 & 2.1 & 50.4 & 3.2 & 1.6 & 1.4 & 50.1 \\
\hline C18:1 & 75.9 & 39.0 & 38.9 & 39.7 & 12.2 & 7.1 & 7.3 & 7.6 \\
\hline C18:2 n-6 & 6.4 & 3.0 & 2.8 & 3.0 & 75.0 & 36.6 & 37.2 & 36.9 \\
\hline $\mathrm{C} 18: 3 \mathrm{n}-3$ & 0.8 & 0.3 & 0.3 & 0.4 & 2.1 & 1.3 & 1.2 & 1.3 \\
\hline $\mathrm{C} 20$ & 0.3 & 0.1 & 0.1 & 0.1 & 0.1 & 0.1 & 0.0 & 0.1 \\
\hline $\mathrm{C} 22$ & 0.4 & 0.1 & 0.1 & 0.1 & 0.1 & 0.1 & 0.0 & 0.1 \\
\hline Total $\mathrm{SFA}^{1}$ & 16.3 & 57.3 & 57.8 & 56.7 & 10.6 & 54.9 & 54.3 & 54.2 \\
\hline Total MUFA ${ }^{2}$ & 76.5 & 39.4 & 39.1 & 39.9 & 12.3 & 7.2 & 7.3 & 7.6 \\
\hline Total PUFA ${ }^{3}$ & 7.2 & 3.3 & 3.1 & 3.4 & 77.1 & 37.9 & 38.4 & 38.2 \\
\hline
\end{tabular}

${ }^{1}$ SFA - saturated fatty acids; ${ }^{2}$ MUFA - monounsaturated fatty acids; ${ }^{3}$ PUFA - polyunsaturated fatty acids

The rats ate all of the diets willingly, but the diets containing the higher acids $\left(\mathrm{C}_{16}\right.$ and $\left.\mathrm{C}_{18}\right)$ were consumed slightly better than others (Table 3 ). Mixing oils with synthetic acids resulted in higher body weight gains. Generally, the longer the carbon chain of the acid, the higher were the body weight gains of rats. These

Table 3. The effect of dietary fat on rat's performance and serum lipid profile in rats

\begin{tabular}{|c|c|c|c|c|c|c|c|c|c|c|}
\hline \multirow{3}{*}{ Indices } & \multicolumn{6}{|c|}{ Main effect means } & \multirow{3}{*}{ SEM } & \multirow{2}{*}{\multicolumn{3}{|c|}{$\begin{array}{c}\text { Significance of } \\
\text { effects }\end{array}$}} \\
\hline & \multicolumn{2}{|c|}{ pure fatty acid $s$} & \multicolumn{2}{|c|}{ supplement (PFA) } & \multicolumn{2}{|c|}{ fat $(F)$} & & & & \\
\hline & $\begin{array}{c}\text { without } \\
\text { SFA }\end{array}$ & C 14:0 & $\mathrm{C} 16: 0$ & C18:0 & $\begin{array}{l}\text { olive } \\
\text { oil }\end{array}$ & $\begin{array}{l}\text { linseed } \\
\text { oil }\end{array}$ & & & & \\
\hline $\begin{array}{l}\text { Daily weight } \\
\text { gain, } g\end{array}$ & $1.55^{\mathrm{D}}$ & $1.99^{\mathrm{C}}$ & $2.39^{\mathrm{B}}$ & $2.57^{\mathrm{A}}$ & 1.72 & 2.53 & 0.043 & $* *$ & $* *$ & $* *$ \\
\hline $\begin{array}{l}\text { Daily feed } \\
\text { intake, g }\end{array}$ & $18.51^{\mathrm{b}}$ & $18.44^{\mathrm{b}}$ & $18.86^{\mathrm{a}}$ & $18.91^{\mathrm{a}}$ & 18.49 & 18.87 & 0.423 & * & $*$ & $*$ \\
\hline $\begin{array}{l}\text { Feed conversion } \\
\text { ratio }^{1}\end{array}$ & $12.17^{\mathrm{A}}$ & $10.04^{\mathrm{B}}$ & $8.19^{\mathrm{C}}$ & $7.68^{\mathrm{D}}$ & 11.12 & 7.91 & 0.470 & $* *$ & $* *$ & $* *$ \\
\hline $\begin{array}{l}\text { Total cholesterol } \\
\text { TC, } \mathrm{mg} \mathrm{dl}^{-1}\end{array}$ & $77.34^{\mathrm{b}}$ & $84.54^{\mathrm{a}}$ & $77.14^{\mathrm{b}}$ & $80.41^{\mathrm{ab}}$ & 81.00 & 78.70 & 1.500 & $*$ & NS & NS \\
\hline HDL-C, $\mathrm{mg} \mathrm{dl}^{-1}$ & 50.42 & 51.51 & 57.29 & 52.86 & 52.34 & 53.70 & 2.118 & NS & NS & NS \\
\hline LDL-C, $\mathrm{mg} \mathrm{dl}^{-1}$ & $27.09^{\mathrm{B}}$ & $32.03^{\mathrm{A}}$ & $25.20^{\mathrm{B}}$ & $27.54^{\mathrm{B}}$ & 31.42 & 24.50 & 1.273 & $* *$ & $* *$ & $*$ \\
\hline HDL-C : TC & $0.643^{\mathrm{ab}}$ & $0.633^{\mathrm{a}}$ & $0.671^{\mathrm{b}}$ & $0.655^{\mathrm{ab}}$ & 0.621 & 0.685 & 0.010 & $*$ & $* *$ & $*$ \\
\hline TAG, $\mathrm{mg} \mathrm{dl}^{-1}$ & $24.07^{\mathrm{C}}$ & $31.03^{\mathrm{A}}$ & $25.69^{\mathrm{BC}}$ & $27.52^{\mathrm{B}}$ & 29.70 & 24.45 & 0.179 & $* *$ & $* *$ & $* *$ \\
\hline
\end{tabular}


differences $(1.99,2.39$ and 2.57 g per day) were statistically highly significant $(\mathrm{P}<0.01)$.

The total cholesterol content in the blood of rats receiving pure linseed oil was lower than that of rats fed with pure olive oil (Figure 1). Myristic acid gave the highest level of TC (Table 3), which was a result of the significantly larger LDL fraction, thus in the case of this acid, the lowest HDL-C, TC ratio was found. Rats fed with myristic acid also had the highest serum TAG content, which was especially apparent in the case of olive oil (Figure 1).
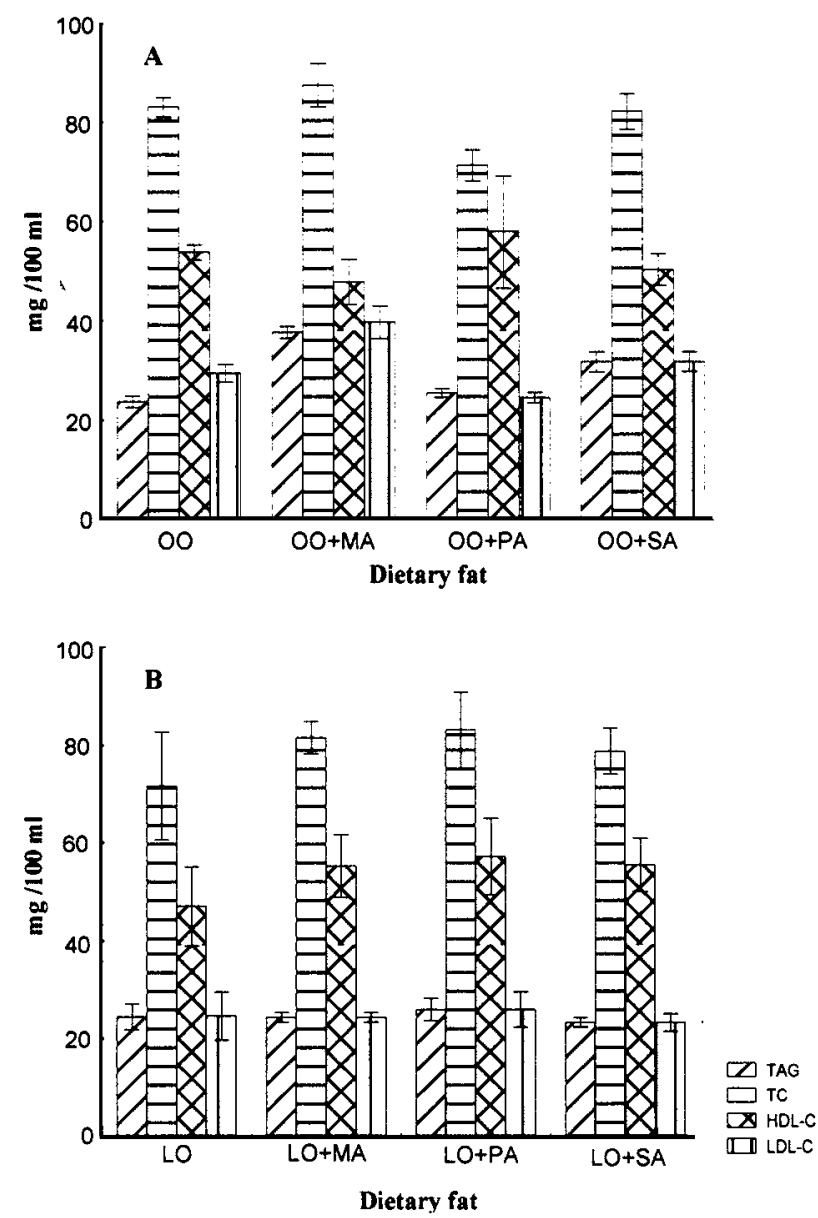

OO-olive oil; LO-linseed oil: MA-mynistic acid; PA-palmitic acid: SA-stearic acid

Figure 1. Effect of olive (A) and linseed (B) oils supplemented with pure saturated fatty acids on serum lipids profile $(\mathrm{mg} / 100 \mathrm{ml})$ in rats (the bars denote $\mathrm{SE}$ ) 


\section{DISCUSSION}

In experiments on using different fats and their effects on lipid metabolism, no distinct changes in body weights of animals are usually found. Although in an experiment on guinea pigs Fernandez et al. (1996) found differences in final body weights to be about $60 \mathrm{~g}$ (about $8 \%$ ), they were not statistically significant. Our results are not consistent with this rule. The high body weight gains of rats consuming experimental mixtures were probably a result of the high saturated fatty acid content of these diets (about $50 \%$ of fat) and greater fat deposition. Greater fat deposition by chickens fed saturated fatty acids was found by Crespo and Esteve-Garcia (2002). According to these authors, this resulted from unsaturated fatty acids lowering liver fatty acid synthetase activity and, as a consequence, lower fat synthesis. Lower fat deposition by animals receiving unsaturated fatty acids could also result from stimulation of the activity of fatdecomposing enzymes (Sanz et al., 2000). Less fat deposition and smaller body weight gains of rats consuming unsaturated fatty acids may also be a consequence of more intense thermogenesis and, consequently, higher energy consumption (Javadi et al., 2004).

All of the diets were eaten willingly, which is contrary to the results of Billet et al. (2000). They used synthetic triacylglycerols in their experiment on hamsters. The diets were not readily eaten and the animals lost weight. It is possible that these differences resulted from the differences in the compounds and species of animals used.

It is generally accepted that polyunsaturated fatty acids lower blood cholesterol levels (Fernandez et al., 2001; Kris-Etherton, 2003). According to these authors, linoleic acid is strongly hypocholesterolaemic. Also in this experiment, pure linoleic acid-rich linseed oil accounted for the lower content of TC in the rats' blood than olive oil. Unfortunately, it also accounted for the lower content of the HDL-C fraction.

When compared with linseed oil, olive oil, which is rich in monounsaturated oleic acid, did not elicit an hypocholesterolaemic effect. Also Fernandez et al. (1996) found that olive oil gave a relatively high cholesterol level, especially its LDL fraction. In this experiment, the level of the LDL fraction when olive oil was used was almost the same as with linseed oil, but the "good" HDL fraction was higher.

According to Hegsted et al. (1965), stearic and oleic acids have no effect on TC, but myristic acid is 4 times as cholesterolaemic as palmitic acid. Also Kris-Etherton (1993) found myristic acid hyper-, while stearic acid rather hypocholesterolaemic. In this experiment, myristic acid mixed with olive oil had hypercholestaerolaemic activity, especially in the case of the LDL-C fraction. Thus, though myristic and 
palmitic acids were slightly hypercholesterolaemic, the differences were not as significant as those found by Hegsted et al. (1965).

The cholesterolaemic activity of fats and fatty acids probably depends on the effect of other dietary components. Pronczuk et al. (1994) found that palmitic acid is cholesterolaemic only when cholesterol is present in the diet. In the experiment of Kummerow et al. (1993), supplementation of diets with magnesium leveled out differences in the cholesterolaemic effect of butter (rich in oleic and palmitic acids) and margarine (rich in oleic and linoleic acids).

\section{CONCLUSIONS}

It can be stated in conclusion that addition of pure $\mathrm{C}_{14}-\mathrm{C}_{18}$ saturated fatty acids to olive and linseed oils increased the body weights of rats and increased total cholesterol, but not its HDL fraction in blood.

\section{REFERENCES}

Allain C.C, Poon L.S., Chan C.S., Richmond W., Fu P.C., 1974. Enzymatic determination of total serum cholesterol. Clin. Chem. 20, 470-475

Benz R., Suter P.M., 2004. Low HDL-cholesterol, high triglicerides - well known but often ignored. Schweiz Rundsch. Med. Prax. 93, 1911-1916

Billet M.A., Bruce J.S., White D.A., Bennet A.J., Salter A.M., 2000. Interactive effects of dietary cholesterol and different saturated fatyy acids on liporotein metabolism in the hamster. Brit. J. Nutr. 84, 439-447

Crespo N., Esteve-Garcia E., 2002. Nutrient and fatty acids deposition in broilers fed different dietary fatty acid profiles. Poultry Sci. 81, 1533-1542

Dorfman S.E., Wang S., Vega-Lopez S., Jauhiainen M., Lichtenstein A.H., 2005. Dietary fatty acids and cholesterol differentially modulate HDL cholesterol metabolism in Golden-Syrian hamsters. J. Nutr. 135, 492-498

Eggum B.O., 1973. A study of certain factors influencing protein utilization in rats and pigs. Beret. Forsoegslab. Statens. Husdyrbrugsudvalg. 406, 17-30

Fernandez M.L., Soscia A.E., Sun G.S., Tosca M., McNamara D.J., McDonald B.E., 1996. Olive oil and rapeseed oil differ in their effect on plasma low-density liporotein metabolism in the guinea pig. Brit. J. Nutr. 76, 869-880

Fernandez M.L., West K.L., Roy S., Ramjiganesh T., 2001. Dietary fat saturation and gender/ hormonal status modulate plasma lipids and lipoprotein composition. J. Nutr. Biochem. 12, 703-710

Flickinger B.D., Huth P.J., 2004. Dietary fats and oils, technologies for improving cardiovascular health. Curr. Atheroscler. Rep. 6, 468-476

Hanczakowski P., Szymczyk B., Szczurek W., 2004. The effect of pure saturated fatty acids on cholesterol and triacylglycerols level in rats. Ann. Anim. Sci. 4, 145-153

Hegsted D.M., Mc Gandy R.B., Myers M.L., Stare F.J., 1965. Quantative effects of dietary fat on serum cholesterol in man. Amer. J. Clin. Nutr. 17, 281-295 
Javadi M., Everts H., Hovenier R., Kocsis S., Lankhorst A.E., Lemmens A.G., Schonewille J.T., Terpstra A.H., Beynen A.C., 2004. The effect of six different C18 fatty acids on body fat and energy metabolism in mice. Brit. J. Nutr. 92, 391-399

Kris-Etherton P.M., 1993. Effects of chain length of saturated fatty acids on plasma total, LDL- and HDL-cholesterol levels. Fat Sci. Technol. 95, 448-452

Kummerow F.A., Wasowicz E., Smith T., Yoss N.L., Thiel J., 1993. Plasma lipid physical properties in swine fed margarine or butter in relation to dietary magnesium intake. J. Amer. Coll. Nutr. $12,125-132$

Mc Gowan M.W., Artiss J.D., Strandbergh D.R., Zak B., 1983. A peroxidase-coupled-method for the colorimetric determination of serum triglicerides. Clin. Chem. 29, 538-542

Nagata J., Kasai M., Negishi S., Saito M., 2004. Effects of structured lipids containing eicosapentaenoic or docosahexoenoic acid and caprylic acid on serum and liver lipid profiles in rats. Biofactors 22, 157-160

Nielsen L.B., Leth-Espensen P., Nordestgaard B.G., Foged E., Kjeldahl K., Stender S., 1995. Replacement of saturated dietary fat, effect on atherogenesis in cholesterol-fed rabbits clamped at the same plasma cholesterol level. Brit. J. Nutr. 74, 509-521

Perona J.S., Canizares J., Montero E., Sanchez-Dominguez J.M., Ruiz-Gutierrez V., 2003. Plasma lipid modifications in elederly people after administration of two virgin olive oils of the same variety (Olea europea var. hojiblanca) with different triacylglycerol composition. Brit. J. Nutr. 89, 819-826

Pronczuk A., Khosla P., Hayes K.C., 1994. Dietary myristic, palmitic and linoleic acid modulate cholesterolemia in gerbils. FASEB J. 8, 1191-1200

Rajaram S., Burke K., Connel B., Muint T., Sabate J., 2001. A monounsaturated fatty acid -rich pecan-enriched diet favorably alters the serum lipid profile of healthy men and women. J. Nutr. $131,2275-2279$

Sanz H., Lopez-Bote C.J., Menovo D., Bautista J.M., 2000. Abdominal fat deposition and fatty acid synthesis are lower and $\beta$-oxidation is higher in broiler chickens fed diets containing unsaturated rather than saturated fat. J. Nutr. 130, 3034-3037

Trautwein E.A., Rieckhoff D., Kunath-Rau A., Erbersdobler H.F., 1999. Replacing saturated fat with PUFA-rich (sunflower oil) or MUFA-rich (rapeseed, olive and high-oleic sunflower oil) fats resulted in comparable hypocholesterolemic effects in cholesterol-fed hamsters. Ann. Nutr. Metabol. 43, 159-172

Warrick G.R., Berdersond J., Alberts J.J., 1982. Dextran-sulphate-Mg precipitation procedure for quantitation of high-density lipoprotein cholesterol. Clin. Chem. 28, 1379-1388 